\title{
BIODETERIORATION OF COASTAL CONCRETE STRUCTURES BY MACRO ALGAE - ULVA FASCIATA
}

Stri Hari Babu Jayakumar

Department of Civil Engineering, Sri Manakula Vinayagar Engineering College, Madagadipet, Pondicherry - 605 107, India., jkss@sify.com

Rama Saravanane

Department of Civil Engineering, Pondicherry Engineering College, Pondicherry - 605 014, India.

Thirumalai Sundararajan

Department of Civil Engineering, Pondicherry Engineering College, Pondicherry - 605 014, India.

Follow this and additional works at: https://jmstt.ntou.edu.tw/journal

Part of the Civil and Environmental Engineering Commons

\section{Recommended Citation}

Jayakumar, Stri Hari Babu; Saravanane, Rama; and Sundararajan, Thirumalai (2011) "BIODETERIORATION OF COASTAL CONCRETE STRUCTURES BY MACRO ALGAE - ULVA FASCIATA," Journal of Marine Science and Technology. Vol. 19: Iss. 2, Article 7.

DOI: $10.51400 / 2709-6998.2150$

Available at: https://jmstt.ntou.edu.tw/journal/vol19/iss2/7

This Research Article is brought to you for free and open access by Journal of Marine Science and Technology. It has been accepted for inclusion in Journal of Marine Science and Technology by an authorized editor of Journal of Marine Science and Technology. 


\title{
BIODETERIORATION OF COASTAL CONCRETE STRUCTURES BY MACRO ALGAE - ULVA FASCIATA
}

\author{
Stri Hari Babu Jayakumar*, Rama Saravanane**, and Thirumalai Sundararajan**
}

Key words: marine algae, marine structures, Ulva fasciata, concrete, deterioration.

\begin{abstract}
Puducherry is a coastal region in India where the growth of Ulva fasciata (Delile) is very abundant on all marine structures. Though the detrimental effect of this macro algae $U$. fasciata is a secondary one, its effect has to be investigated. To know its effect, the basic mechanism by which $U$. fasciata deteriorates concrete structures has been highlighted. To ascertain its detrimental effect on coastal concrete structures, M20 grade concrete cubes were casted and immersed in the coastal area where there is abundant growth of $U$. fasciata. In addition laboratory simulation has been carried out. Concrete samples collected from the coastal area and from the laboratory were analyzed by SEM, EDX and XRD to establish the degree of deterioration done by marine algae on concrete surface. The result showed that there is sustainable effect by the marine algae on the concrete surface.
\end{abstract}

\section{INTRODUCTION}

About $71 \%$ of the world is surrounded by ocean. The most important herbivores in ocean are phytoplankton and benthic algae. The marine algae familiarly known as seaweeds are a diverse group of photoautotrophic organisms of various shapes (filamentous, ribbonlike, or platelike) that contain pigments such as chlorophyll, carotenoids, and xanthophylls. The growth of marine algae is abundant in coastal area since sandy beaches provide excellent attachment points in a constantly moving and dynamic environment of the sandy shore. The first type of plant life to attach itself to these structures is filamentous Macroalage. The colonisation is likely to be, due to the constant abrasion of the lower regions by the action of

Paper submitted 07/15/09; revised 01/15/10; accepted 03/11/10. Author for correspondence: S. Jayakumar (e-mail: jkss@sify.com).

*Department of Civil Engineering, Sri Manakula Vinayagar Engineering College, Madagadipet, Pondicherry - 605 107, India.

**Department of Civil Engineering, Pondicherry Engineering College, Pondicherry - 605 014, India. the tide lifting the sand and small stones from around the base of the structure. A number of seaweeds can be found in this type of environment although there is usually a few dominant species like $U$. fasciata. These green algae are classified in the phylum Chlorophyta. Many species of green algae grow attached to rocky and concrete substrates on or near the ocean's surface. In general, because they are attached to a substrate, they are not tossed up on the beach by the waves. These macroalgae are able to obtain different elements for their metabolism e.g. calcium, aluminum, silicon, iron etc by biosolubilization of materials. Such biosolubilization involves the production of organic acids by the metabolic activity of macroalgae. This acid deterioration is one of the best known biogeochemical mechanism of concrete decay $[12,17,18]$.

To better understand the terminology and chemical process, they are explained as follows:

\section{Biogeochemical Deterioration Mechanism}

The biogenic (produced by living organisms or biological processes) release of corrosive acids is probably the best known and most commonly investigated biogeochemical damage mechanism in inorganic materials like concrete. The process, known as biocorrosion, is known to be caused by the microbial secretion of inorganic and organic acids (acidolysis and complexation). These agents are capable of leaching the mineral matrix with subsequent weakening of the bindingsystem.

\section{Biocorrosion}

Kinetics of corrosion processes of metals, mineral and other materials can be influenced by biofilms. Products of their metabolic activities including enzymes, exopolymers, organic and inorganic acids, as well as volatile compounds such as ammonia or hydrogen sulphide can affect cathodic and/or anodic reactions, thus altering electrochemistry at the biofilm/ metal interface. This phenomena is often referred to as "biocorrosion" or "microbially influenced corrosion" (mic).

A biofilm is a structured community of microorganisms encapsulated within a self-developed polymeric matrix and adherent to a living or inert surface. Biofilms are also often characterized by surface attachment, structural heterogeneity, 


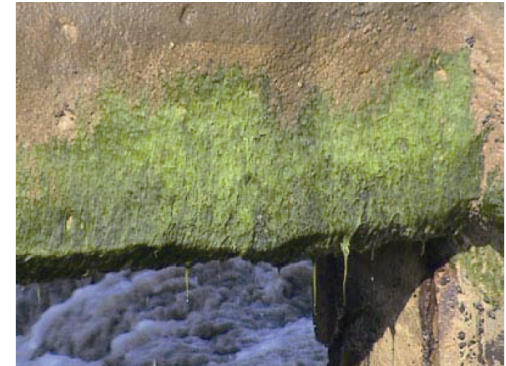

Fig. 1. Growth of marine seaweed on structural components.

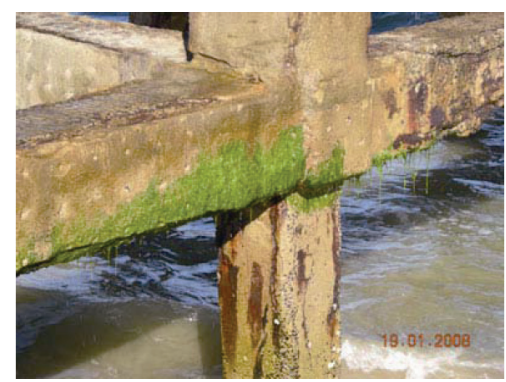

Fig. 2. Growth of marine seaweed on structural components.

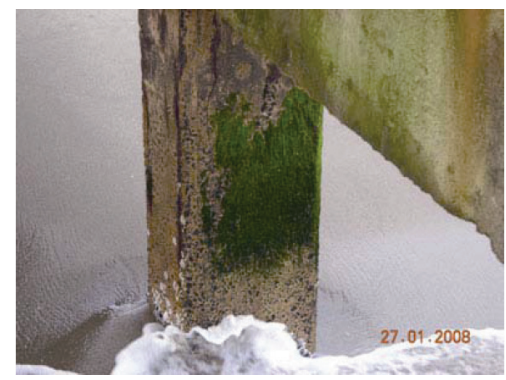

Fig. 3. Growth of marine seaweed on structural components.

genetic diversity, complex community interactions, and an extracellular matrix of polymeric substances.

Biodeterioration is any undesirable change in the properties of a material caused by the vital activities of organisms.

Phycochemistry is the study of natural products and chemical constituents occurring within algal thalli from biological view point. Various natural products includes fatty acids (saturated and unsaturated), sterols, terpenoids and sugars.

Puducherry is an Indian coastal region on the Bay of Bengal. There are many marine structures located in the coastal area. These structures deteriorate due to the macro flora present in the sea water as shown in Figs. 1, 2, 3 [3, 4, 6, 7]. Though a secondary deterioration process, there is significant effect due to this macro flora $[9,15,16]$. The ambient condition prevailing in the coastal area helps the growth of $U$. fasciata round the year. The growth of $U$. fasciata on concrete struc- ture in Puducherry region is found almost on all the structures. This study aims to ascertain the effect of marine chlorophyceae U. fasciata on concrete structure. For this, concrete cubes were immersed in the coastal area where there is abundant growth of $U$. fasciata and a parallel study was made in the laboratory. Phycochemical analysis of $U$. fasciata was carried on to find the chemical constituents occurring in the algae due to secondary metabolites. The surface of the concrete cube is chipped where there is a growth of $U$. fasciata. Their morphological characteristics were observed using Scanning Electron Microscope (SEM) and surface analysis was done using Energy Dispersive X-ray analysis (EDAX). Mineralogical analysis is done using X-ray Diffraction (XRD). The importance of surface analysis and mineralogical analysis is as follows:

SEM is used in petrographic analysis of cementitious materials and concrete microstructure. SEM imaging provides detailed images of the microstructure that augment those from stereo and optical microscopy. The primary advantages are the high-contrast images of the microstructure.

EDAX technique is used for identifying the elemental composition of the specimen. The EDAX analysis system works as an integrated feature of a scanning electron microscope (SEM), and can not operate on its own without the latter.

$\mathrm{X}$-ray diffraction techniques (XRD) are non-destructive analytical techniques which reveal information about the crystallographic structure, chemical composition, and physical properties of materials and thin films. These techniques are based on observing the scattered intensity of an X-ray beam hitting a sample as a function of incident and scattered angle, polarization, and wavelength or energy.

\section{MATERIALS AND METHODS}

\section{Concrete Cubes}

To ascertain the effect of $U$. fasciata on concrete, concrete cubes of M20 grade (Recommended in Indian Standard (IS 456-2000)) were used. M20 grade concrete mix with watercement ration 0.5 is used for severe exposure condition. The cubes were prepared using OPC 53 Grade cement, which is high quality cement prepared from the finest raw material. Due to optimum water demand, OPC 53 grade contributes to a very low coefficient of permeability of the concrete prepared. This improves the density of the concrete matrix and increases the durability of the concrete.

\section{Methods}

The procedure followed to determine the effects of $U$. fasciata on concrete cubes were

a) To culture $U$. fasciata naturally, several concrete cubes were kept in coastal area where there was abundant growth of U. fasciata (Fig. 4)

b) Concrete cubes were allowed to cure in ordinary water.

c) Laboratory simulation has been carried out to culture the 


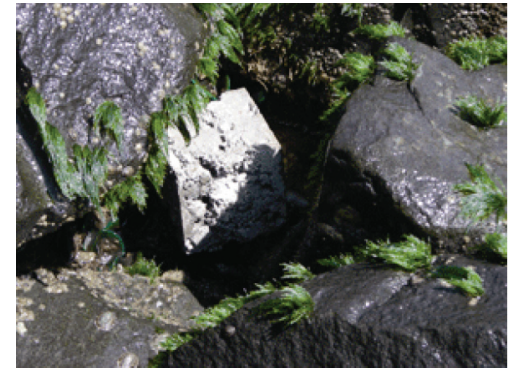

Fig. 4. Natural culture of the marine algae $U$. fasciata on concrete cube.

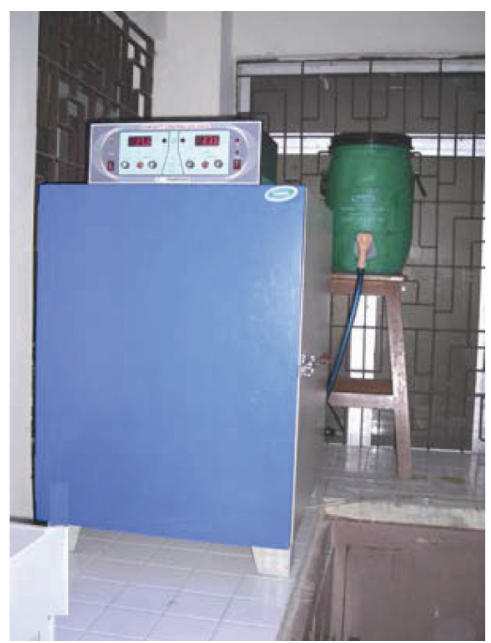

Fig. 5. Laboratory culture of the marine algae $U$. fasciata on concrete cube.

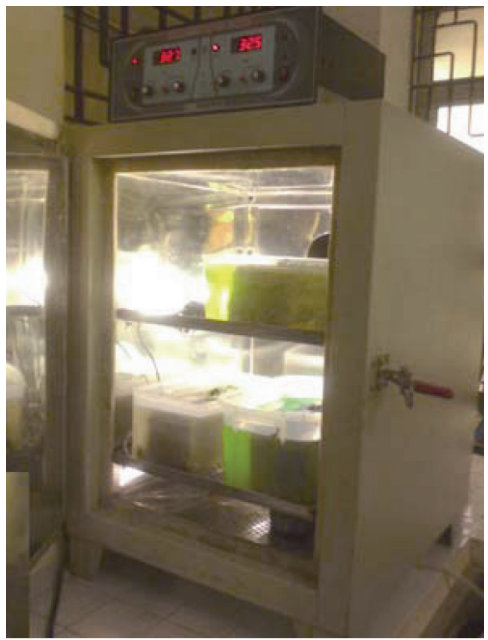

Fig. 6. Laboratory culture of the marine algae $U$. fasciata on concrete cube.

macro algae on the concrete cube. For the simulation, Humidity oven was used (Figs. 5, 6). The details of oven are as follows:

\section{1) Construction}

Double walled, inner S.S.304 / 316 grade \& outer S. Steel or GI dully Epoxy Powder coat/finish, gap filled with Glass wool with outer metallic door provided. Chamber is illuminated with bulb.

\section{2) Cooling Facility}

By Hermetically sealed branded compressor coupled with air cooled condensing unit fitted with Motor, fan blade, Electrical Accessories etc.. Mounted on bottom of unit on heavy base frame.

\section{3) Humidity Creation}

Humidity Created with Steam and injected into working chamber.

\section{4) Heating Facility}

By long lasting Stainless Steel Tubular Heater with fins.

\section{5) Temperature Control}

Electronic Digital Temperature Controller-Cum Indicator with Dry Bulb and Wet Bulb principle.

The ambient condition maintained in the chamber is as follows. Samples were incubated under lighting conditions of 2000 lx, 12 h/day with a "daylight" with white fluorescent lamp. The temperature is maintained at $30^{\circ} \mathrm{C}$. The relative humidity is maintained as $90 \%$ [3].

To ascertain the detrimental effect of marine algae on concrete, 50 cubes were kept in coastal area where there is abundant growth of algae. Every three months, four cubes were tested to ascertain the effect of marine algae on the cubes. Totally 20 cubes has been tested for the past one and half years and the cubes tested after nine months only showed predominant changes in the surface analysis done using SEM and EDAX and mineralogical analysis using XRD. Moreover the concrete cubes showed a weight loss of around $0.4 \mathrm{~kg}$ after nine months.

The laboratory simulated concrete cubes were tested after six months and here also there is sustainable effect after eight months only and weight loss in this case is $0.6 \mathrm{~kg}$.

\section{Samples and Microbiological Procedures}

Concrete sample for analysis were taken from the concrete cube where $U$. fasciata had attached itself from natural conditions. Before chipping the concrete surface for analysis, the biomass namely the marine chlorophyceae grown on the surface was scarped and placed in sterile plastic vessel and taken to the laboratory for identification. Apart from this concrete sample was chipped from the concrete cubes immersed in ordinary water in the laboratory.

\section{Morphological Observations and Surface Analysis}

SEM was employed in studying the morphological characteristics of the structure. For this, samples were dehydrated using acetone; critical point dried; and gold coated at $10^{-3} \mathrm{~mm}$ $\mathrm{Hg}$ in sputter coat apparatus prior to SEM observations and EDAX analysis using a Hitachi S-3400N microscope. 


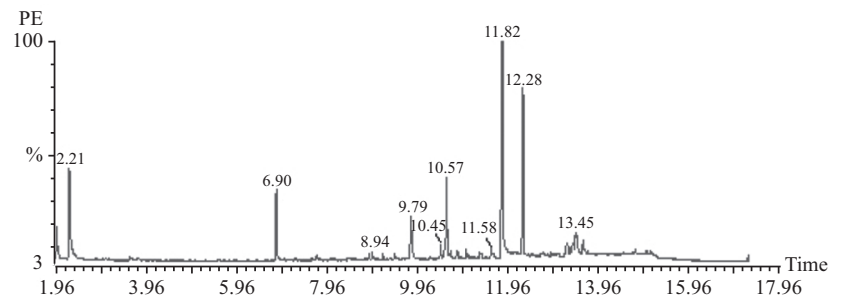

Fig. 7. GC-MS of fatty acid fractions subjected to methylation obtained from $U$. fasciata.

\section{Mineralogical Characterization}

The concrete samples were analyzed by powder X-ray Diffraction using Philips PW1710 diffractometer with an automatic slit under the following conditions: emission radiation $=\mathrm{CuK} \alpha$, voltage $=40 \mathrm{kV}$, intensity $=30 \mathrm{nA}$, gonimeter speed $=0,120 / \mathrm{s}$. Gonimeter calibration was performed using silica standard. Data was interpreted using X'Pert High Score. Samples were ground in agar mortar and sieved to obtain a fraction of particle size less than $53 \mu \mathrm{m}$.

\section{Phycochemical Investigation of Marine Algae U. fasciata}

Marine algae $U$. fasciata was collected from the coastal area of Puducherry. It was washed thoroughly to remove epiphytes, animal casting, attached detritus and sand particles. Then it was rinsed with distilled water and shadow dried with aeration to avoid the breakdown of secondary metabolites under sunlight and high temperature. The dried algal materials were chopped and milled. The following procedures were followed to isolate fatty acid from the dried algae:

\section{1) Extraction}

The dried, chopped and milled algal material was then soaked in methanol $(\mathrm{MeOH})$ in a large glass jar and was kept in the solvent for one month at room temperature. The extract of the material thus obtained was then filtered to remove all solid algal particles. Next it was evaporated on a rotary evaporator under reduced pressure. This yielded a dark green, thick residue.

\section{2) Saponification}

An aliquot of the extract obtained was saponified with $10 \%$ $\mathrm{KOH}$ in $50 \%$ methanol and refluxed at $100^{\circ} \mathrm{C}$ for 6 hours. The mixture was then concentrated under reduced pressure and then $\mathrm{H}_{2} \mathrm{O}$ and diethyl ester $\left(\mathrm{Et}_{2} \mathrm{O}\right)$ were added. It was then shaken vigorously and the $\mathrm{Et}_{2} \mathrm{O}$ layer was separated. The $\mathrm{Et}_{2} \mathrm{O}$ layer was evaporated and used for fatty acid analysis.

\section{3) Esterification}

All the fatty acid fractions obtained were subjected to methylation and 1.5-2.0 mL ethereal diazomethane was added to the fatty acid mixture. The reaction mixture was left in the fuming chamber at room temperature, over night until dissolved. The aliquots were then directly injected to a Hewlett
Table 1. Types of fatty acids present in $U$. fasciata.

\begin{tabular}{|c|c|c|c|}
\hline $\begin{array}{c}\text { Acid } \\
\text { type }\end{array}$ & Systematic name & Common name & $\begin{array}{c}\text { Molecular } \\
\text { formula }\end{array}$ \\
\hline \multicolumn{5}{|c|}{ Saturated fatty acids } \\
\hline $\mathrm{C} 14: 0$ & n-Tetradecanoate & Myristate & $\mathrm{C}_{15} \mathrm{H}_{30} \mathrm{O}_{2}$ \\
\hline $\mathrm{C} 17: 0$ & n-Hexadecanoate & Palmitate & $\mathrm{C}_{17} \mathrm{H}_{34} \mathrm{O}_{2}$ \\
\hline $\mathrm{C} 19: 0$ & n-Nonadecanoate & Nonadecylate & $\mathrm{C}_{20} \mathrm{H}_{40} \mathrm{O}_{2}$ \\
\hline \multicolumn{5}{|c|}{ Monoenoic fatty acids } \\
\hline $\mathrm{C} 13: 1$ & Tridecenoate & Decylacrylate & $\mathrm{C}_{14} \mathrm{H}_{26} \mathrm{O}_{2}$ \\
\hline $\mathrm{C} 19: 1$ & Nonadecenoate & Nonadecylenate & $\mathrm{C}_{20} \mathrm{H}_{38} \mathrm{O}_{2}$ \\
\hline $\mathrm{C} 21: 1$ & Heneicosenoate & - & $\mathrm{C}_{21} \mathrm{H}_{42} \mathrm{O}_{2}$ \\
\hline $\mathrm{C} 29: 1$ & Nonacocenoate & - & $\mathrm{C}_{30} \mathrm{H}_{58} \mathrm{O}_{2}$ \\
\hline \multicolumn{5}{|c|}{ Dienoic fatty acid } \\
\hline C17:2 & $9,12,15$ Heptaedcaienoate & - & $\mathrm{C}_{18} \mathrm{H}_{32} \mathrm{O}_{2}$ \\
\hline $\mathrm{C} 18: 2$ & Octadecadienoate & Linoleate & $\mathrm{C}_{19} \mathrm{H}_{34} \mathrm{O}_{2}$ \\
\hline
\end{tabular}

Packard gas chromatograph-mass spectrophotometer (GC-MS) with 11/73 DEC computer system.

The methanolic extract of $U$. fasciata (Fig. 7) revealed the presence of three saturated and six unsaturated fatty acids. The details are listed in Table 1.

\section{4) Experimental Method-Flow Chart}

The below chart shows the schematic way of experimental work carried on to determine the effect of marine algae on concrete

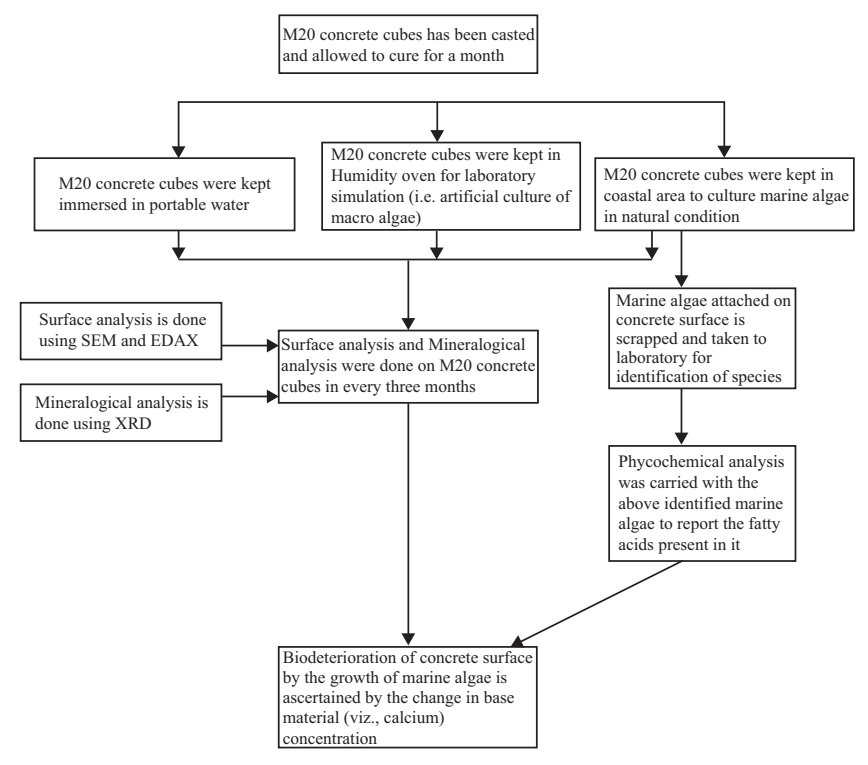

\section{RESULTS AND DISCUSSION}

\section{Macro-Algae Results}

The species collected by scarping from the surface of concrete was identified as $U$. fasciata Fig. 8. 
Table 2. EDAX analysis of concrete specimen immersed in ordinary water- (control concrete).

\begin{tabular}{cc}
\hline Element Line & Atom \% \\
\hline O K & 58.44 \\
Mg K & 11.76 \\
$\mathrm{Al} \mathrm{K}$ & 6.38 \\
$\mathrm{Si} \mathrm{K}$ & 10.37 \\
$\mathrm{~S} \mathrm{~K}$ & 1.08 \\
$\mathrm{~S} \mathrm{~L}$ & --- \\
$\mathrm{K} \mathrm{K}$ & 0.25 \\
$\mathrm{~K} \mathrm{~L}$ & --- \\
$\mathrm{Ca} \mathrm{K}$ & 9.18 \\
$\mathrm{Ca} \mathrm{L}$ & --- \\
Fe K & 2.55 \\
Fe L & --- \\
Total & 100.00 \\
\hline
\end{tabular}

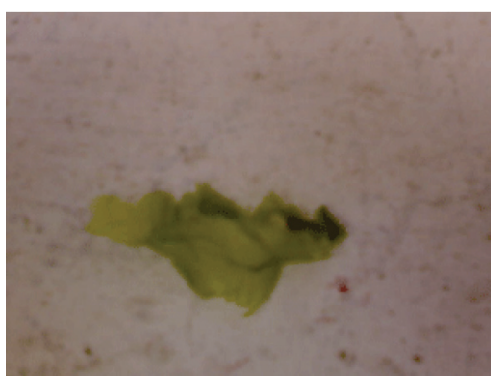

Fig. 8. U. fasciata species.

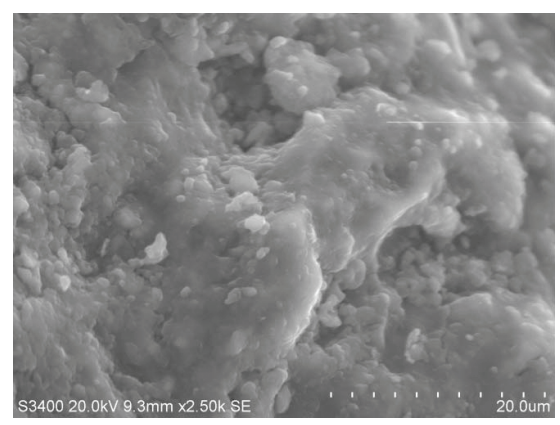

Fig. 9. SEM of concrete specimen immersed in ordinary water (magnification: $\mathbf{x 2 5 0 0}$ ) - (control concrete).

\section{Biodeterioration Mechanisms}

The release of metabolic acids is one of the best-known biogeochemical destructive mechanisms on concrete surfaces [12, 17], with leaching of concrete binding materials [11] and consequent weakening of the crystal structure. These acids are also capable of chelating cations such as $\mathrm{Ca}, \mathrm{Al}, \mathrm{Si}, \mathrm{Fe}, \mathrm{Mn}$ and $\mathrm{Mg}$ from minerals forming stable complexes [1, 2, 8, 13, 14]. It has been shown that biogenic organic acids are considerably more effective in mineral mobilization than inorganic acids and are considered as one of the major damaging agents affecting concrete deterioration.
Table 3. EDAX analysis of $U$. fasciata attached concrete surface in natural condition.

\begin{tabular}{cc}
\hline Element Line & Atom \% \\
\hline O K & 50.59 \\
$\mathrm{Na} \mathrm{K}$ & 0.19 \\
$\mathrm{Mg} \mathrm{K}$ & 0.27 \\
$\mathrm{Al} \mathrm{K}$ & 0.72 \\
$\mathrm{Si} \mathrm{K}$ & 1.29 \\
$\mathrm{~K} \mathrm{~K}$ & 0.63 \\
$\mathrm{Ca} \mathrm{K}$ & 46.06 \\
$\mathrm{Ti} \mathrm{K}$ & 0.04 \\
Fe K & 0.07 \\
Total & 100.00 \\
\hline
\end{tabular}

Table 4. EDAX analysis of $U$. fasciata attached concrete surface in natural condition.

\begin{tabular}{cc}
\hline Element Line & Atom \% \\
\hline $\mathrm{C} \mathrm{K}$ & 0.00 \\
$\mathrm{O} \mathrm{K}$ & 45.14 \\
$\mathrm{Na} \mathrm{K}$ & 3.86 \\
$\mathrm{Mg} \mathrm{K}$ & 2.76 \\
$\mathrm{Si} \mathrm{K}$ & 4.23 \\
$\mathrm{Ca} \mathrm{K}$ & 44.01 \\
$\mathrm{Ca} \mathrm{L}$ & --- \\
Total & 100.00 \\
\hline
\end{tabular}

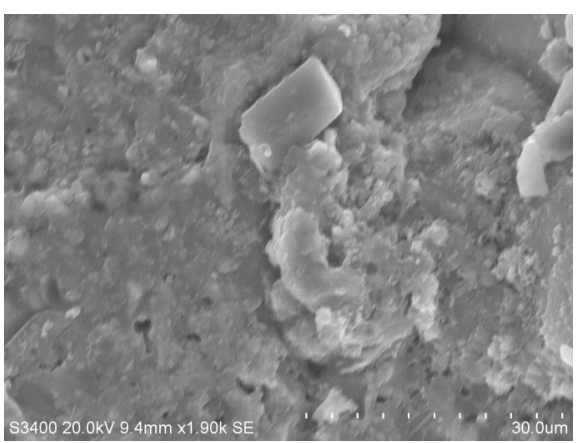

Fig. 10. SEM of $U$. fasciata attached concrete surface in natural condition (magnification: $\mathbf{x 2 5 0 0 )}$.

The net outcome of this type of biodeterioration is the physical and mechanical breakdown of the concrete matrix. (Table 2, Fig. 9, Table 3, Fig. 10, Table 4, Fig. 11, Fig. 12, Fig. 13, Fig. 14)

\section{Discussion}

All surfaces in natural environments either aerial or subaerial are colonized by microorganisms and sub-aerial structures are colonized severely. Concrete is one such material that can be readily colonized by macro algae [10] as is revealed in this work. Macro algae are able to obtain several ele- 


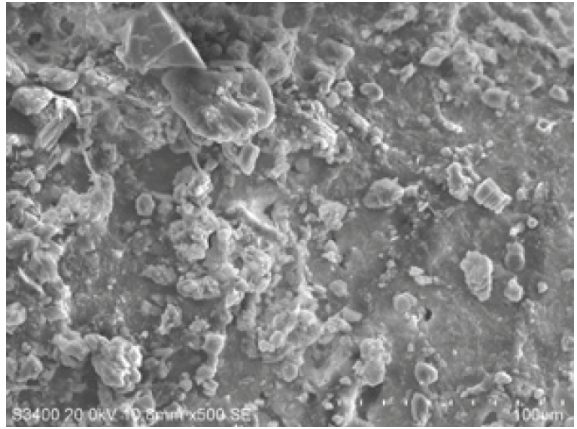

Fig. 11. SEM of $U$. fasciata attached concrete surface in laboratory condition (magnification: x5000).

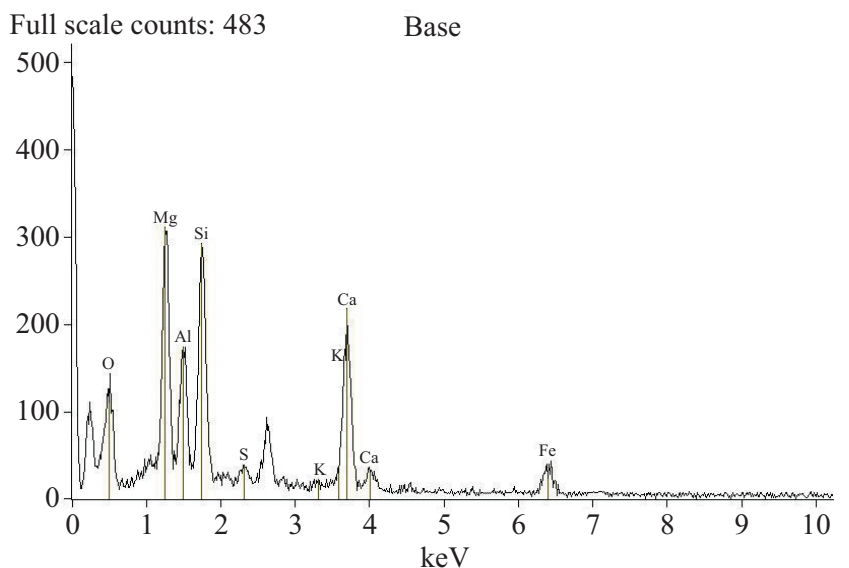

Fig. 12. EDAX of concrete specimen immersed in ordinary water (control concrete).

ments they need for their metabolism (e.g. calcium, aluminium, silicon, iron and potassium) from the concrete $[1,2,8,13$, 14] by biosolubilization in the presence of sea water. This biosolubilization process generally involves the production of various organic acids (listed in Table-1) by marine algae. The release of aggressive acids is one of the best known biogeochemical destructive mechanisms $[12,17,18]$ on concrete surfaces. It occurs through the leaching of binding materials with the consequent weakening of the crystal structure [11]. The final result of this type of biodeterioration is the physical and mechanical breakdown of the concrete [17].

\section{1) Surface Analysis by EDAX}

EDAX results depicted above Tables 2, 3 and 4 elucidate that the base material has been modified. In the case of concrete cubes cured in ordinary water (control concrete) the silica level is $10.37 \%$ atom while calcium level is $9.18 \%$ atom. The EDAX results of the algal affected concrete in natural condition shows that the calcium level has tremendously increased to $46.06 \%$ atom while silica level has been decreased to $1.29 \%$ atom $[6,16]$. While in the case of simulated condition, calcium level has tremendously increased to $44.01 \%$ atom while silica level has been decreased to $4.23 \%$ atom.

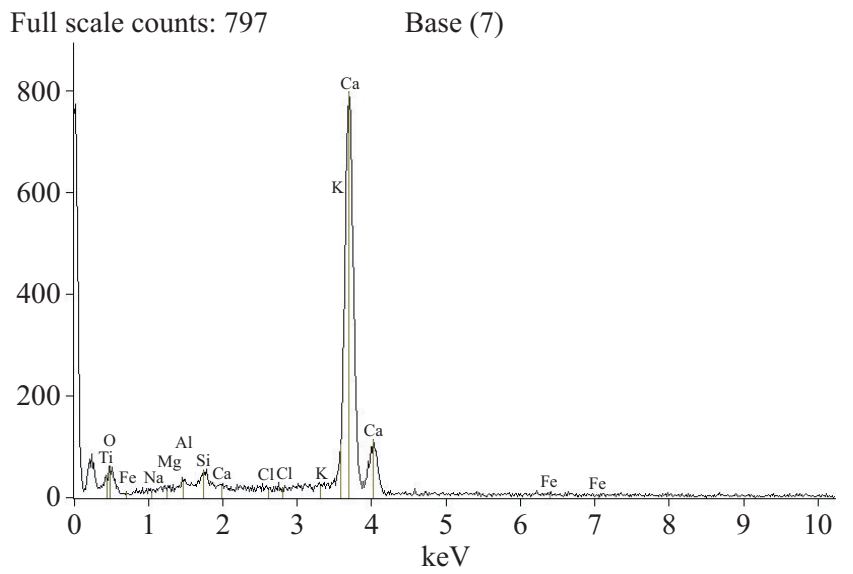

Fig. 13. EDAX of $U$. fasciata attached concrete surface in natural condition.

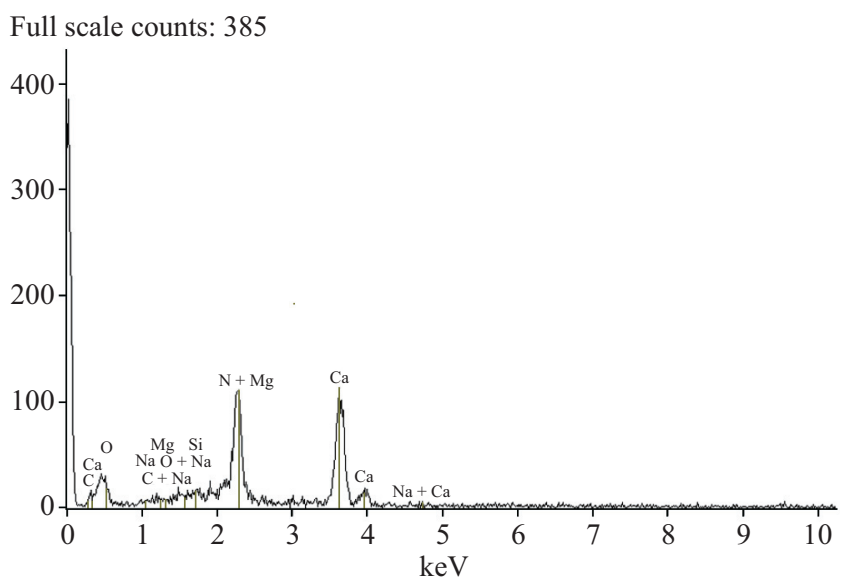

Fig. 14. EDAX of $U$. fasciata attached concrete surface in laboratory condition.

This proves that the calcium level in the algal affected concrete surface in natural condition has increased tremendously. This high level of calcium is due to dissolution of calcium in concrete by organic acid produced by marine chlorophyceae $U$. fasciata and precipitation of the organic salt upon dehydration. This is an indication of the alteration of the base material.

\section{2) Mineralogical Analysis by X-ray Diffraction}

Fig. 15 shows the mineralogical analysis of concrete by XRD. The following are the crystals present in concrete specimen immersed in ordinary water Portlandite $\left(\mathrm{Ca}(\mathrm{OH})_{2}\right)$, Silica, Yeelimite $\left(\mathrm{Ca}_{3} \mathrm{Al}_{6} \mathrm{O}_{12} \cdot \mathrm{CaSO}_{4}\right)$, Gismondine $\left(\mathrm{CaAl}_{2} \mathrm{Si}_{2} \mathrm{O}_{8} \cdot 4 \mathrm{H}_{2} \mathrm{O}\right)$, Dolomite $\left(\mathrm{CaMg}\left(\mathrm{CO}_{3}\right)_{2}\right)$, Maragarite-2 $\left(\mathrm{CaAl}_{2}\left(\mathrm{Si}_{2} \mathrm{Al}_{2}\right) \mathrm{O}_{10}(\mathrm{OH})_{2}\right)$, Calcium Silicate Hydroxide $\left(\mathrm{Ca}_{4} \mathrm{H}_{2} \mathrm{O}_{15.5} \mathrm{Si}_{5}\right)$. The intensity of Portlandite is 34 at $18^{\circ}, 34^{\circ}, 50^{\circ}$ while silica has a maximum intensity of 846 at $26^{\circ}$ and Calcium Silicate Hydroxide has a intensity of 294 at $28^{\circ}$.

Fig. 16 shows XRD pattern for algal attached concrete in natural condition. Compounds like Foshagite $\left(\mathrm{Ca}_{4} \mathrm{HO}_{11} \mathrm{Si}_{3}\right)$, 


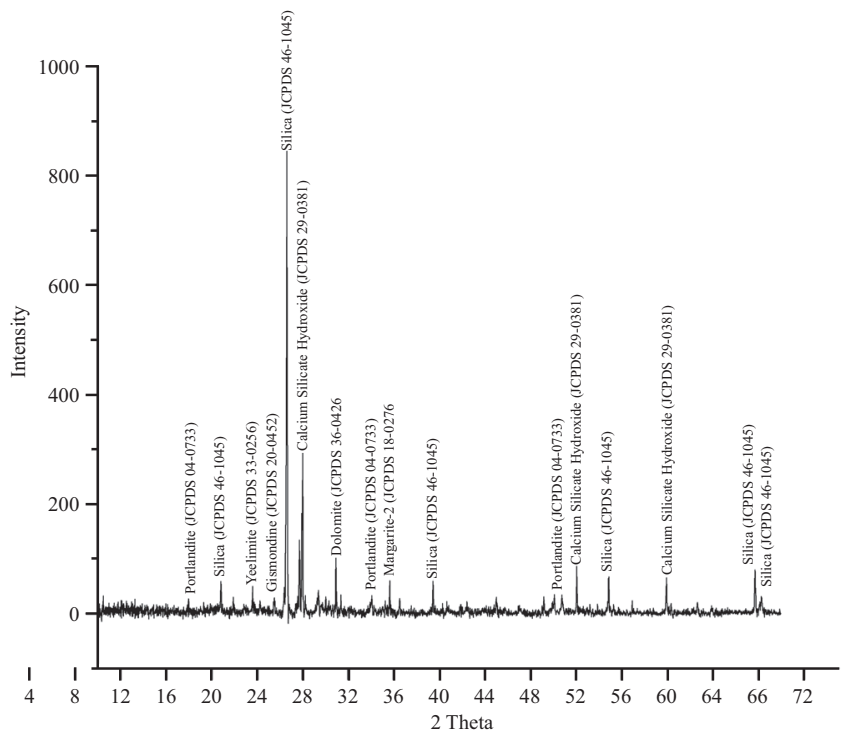

Fig. 15. XRD of concrete specimen immersed in ordinary water (Control concrete).

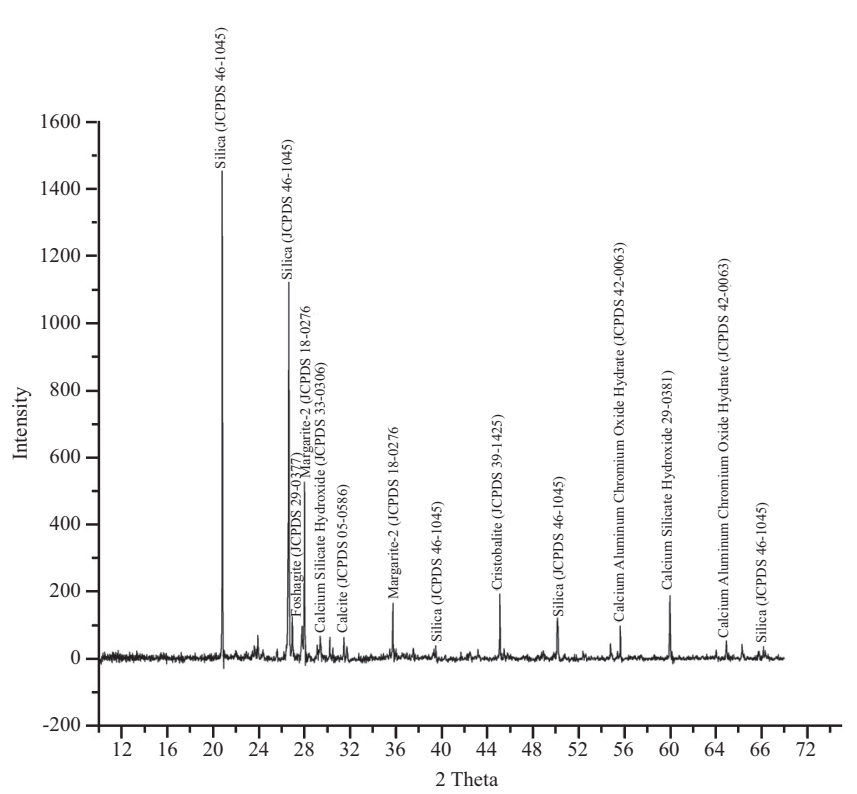

Fig. 16. XRD of $U$. fasciata attached concrete surface in natural condition.

Calcium Silicate Hydrate $\left(\mathrm{Ca}_{1.5} \mathrm{SiO}_{3.5} \cdot \mathrm{xH}_{2} \mathrm{O}\right)$, Calcite $\left(\mathrm{CaCO}_{3}\right)$, and Cristobalite $\left(\mathrm{SiO}_{2}\right)$, Calcium Aluminum Chromium Oxide Hydrate are present here which are absent in the concrete specimen immersed in ordinary water (Control Concrete). Apart from this, it is noticed that the Silica intensity (1452) is very high at $21^{\circ}$ compared to $26^{\circ}$ which is 1119 only. Similarly the intensity of Calcium Silicate Hydroxide at $60^{\circ}$ is 64 in control concrete while it is 187 here. Compounds like Yeelimite, Gismondine and Portlandite are completely absent here. The absence of Portlandite (i.e. Calcium Hydroxide) shows that the alga has utilized it for its metabolic activity.

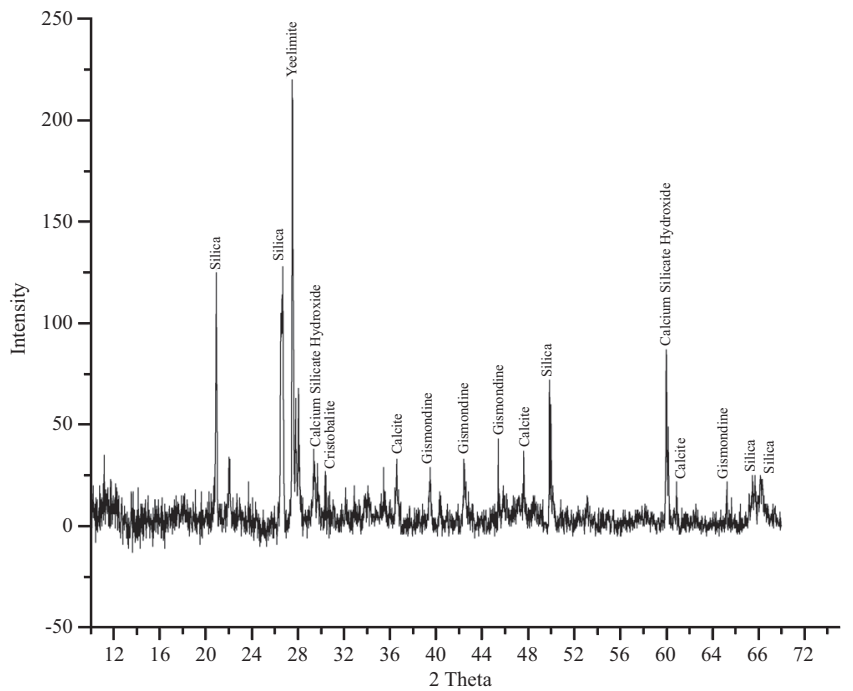

Fig. 17. XRD of $U$. fasciata attached concrete surface in laboratory condition.

Fig. 17 shows the XRD pattern for algae attached concrete in simulated condition. It is notified that the intensity of Yeelimite is very high (218) while there are two Silica peaks at $20^{\circ}$ and $26^{\circ}$ with more or less equal intensity of 126 . The intensity of Calcium Silicate Hydroxide at $60^{\circ}$ is 64 in control concrete while it is 87 here. Apart from this new compounds like Cristobalite and Calcite are present here which is not notified in control concrete. Three peaks are noticeable for portlandite in control concrete which is totally absent in this case. Similarly Margarite-2 is not noticeable here. This shows that algae have utilized this calcium hydroxide for its metabolic activity $[1,2]$.

\section{CONCLUSION}

Samples obtained from the concrete cubes immersed in ordinary water and from the $U$. fasciata attached concrete surface in natural as well as laboratory simulated condition was studied in order to identify the effect of metabolic activity of macro algae $U$. fasciata on concrete. Surface analysis by EDAX suggests that biodeterioration may be performed through a biosolubilization mechanism involving the production of metabolic acids by algae. EDAX results shows us that the calcium level is tremendously increased to $46.06 \%$ in natural and $44.01 \%$ in laboratory simulation while the silica level has decreased remarkably. Also from XRD we are able to see that crystals like Yeelimite, Gismondine and Portlandite which are present in control concrete is completely absent in algal attached concrete and this shows that the marine algae has utilized it for its metabolic activity. Hence, it is concluded that the base material has been altered severely. Thus the presence of chlorophyceae would serve as a primary support for heterotrophic biofilm, providing organic matter for growth through photosynthesis. 


\section{REFERENCES}

1. Bertron, A., Escadeillas, G., and Duchesne, J., "Cement paste alteration by liquid manure organic acids: Chemical and mineralogical characterization," Cement and Concrete Research, Vol. 34, pp. 1823-1835 (2004).

2. De Belie, N., Debruyckere, M., Van Nieuwenburg, D., and De Blaere, B., "Attack of concrete floors in pig houses by feed acids: Influence of fly ash addition and cement-bound surface layers," Journal of Agricultural Research Engineering, Vol. 68, pp. 101-108 (1997).

3. Dubosc, A., Escadeillas, G., and Blanc, P. J., "Characterization of biological stains on external concrete walls and influence of concrete on underlying material," Cement and Concrete Research, Vol. 31, pp 1613 1617 (2001).

4. Gaylarde, C. C. and Gaylarde, P. M., "Phototrophic biomass on monuments of cultural heritage in Latin America," Latincorr '98 Proceedings, Paper S11-03, NACE International, Houston, TX (1998).

5. Guiamet, P. S., Gomez de Saravia, S. G., and Videla, H. A., "Biodeteriorating microorganisms of two archaeological buildings at the site of Uxmal, Mexico," Latincorr '98 Proceedings, Paper S11-01, NACE International, Houston, TX (1998).

6. Herrera, L. K., Arroyave, C., and Guiamet, P., "Biodeterioration of peridotite and other constructional materials in a building of the Colombian cultural heritage," International Biodeterioration \& Biodegradation, Vol. 54, pp. 135-141 (2004).

7. Herrera, L. K., Arroyave, C., and Videla, H. A., "Atmospheric and biological deterioration of two churches from the cultural heritage of the city of Medellin, Colombia,” In: Saiz-Jimenez, C. (Ed.), Molecular Biology and Cultural Heritage, Balkema Publishers, Lisse, The Netherlands, pp. 271-276 (2003).

8. Keller, W. D., Principles of Chemical Weathering, Lucas Brothers Publishers, Columbia, Missouri (1957).

9. McCormack, K., Morton, L. H. G., Benson, J., Osborne, B. N., and McCabe, R. W., "A preliminary assessment of concrete biodeterioration by microorganisms," Microbially Influenced Corrosion of Materials, Springer, Berlin, pp. 168-186 (1996).

10. Ribas Silva, M. and Pinheiro, S. M. M., "Microbial impact on concrete microstructure of world heritage in Brasilia," Proceedings of International RILEM Workshop on Performance Based, RILEM, Madrid, Spain (2006).

11. Sanchez-Silva, M. and Rosowsky, D. V., "Biodeterioration of construction materials: state of the art and future challenges," Journal of Materials in Civil Engineering, ASCE, Vol. 20, pp. 352-365 (2008).

12. Sand, W. "Microbial mechanism of deterioration of inorganic substrates a general mechanistic overview," International Biodeterioration \& Biodegradation, Vol. 40, pp. 183-190 (1997).

13. Schalscha, E. B., Appelt, H., and Schatz, A., "Chelation as weathering mechanisms-I. Effect of complexing agents on the solubilization of iron from minerals and granodiorite," Geochimica et Cosmochimica Acta, Vol. 31, pp. 587-596 (1967).

14. Schatz, A., Schatz, V., and Martin, J. J., "Chelation as a biochemical factor," Geology Society of the American Bulletin, Vol. 68, pp. 1792-1793 (1957).

15. Videla, H. A. and Characklis, W. G., "Biofouling and microbiologically influenced corrosion," International Biodeterioration \& Biodegradation, Vol. 29, pp. 195-212 (1992).

16. Videla, H. A., Guiamet, P. S., and Gomez de Saravia, S., "Biodeterioration of Mayan archaeological sites in the Yucatan Pennsula, Mexico," International Biodeterioration \& Biodegradation, Vol. 46, pp. 335-341 (2000).

17. Warscheid, T. and Braams, J., "Biodeterioration of stone: a review," International Biodeterioration \& Biodegradation, Vol. 46, pp. 343-368 (2000).

18. Warscheid, T. and Krumbein, W. E., "General aspects and selected cases," In: Heitz, E., Flemming, H.-C., and Sand, W. (Eds.), Microbially Influenced Corrosion of Materials, Springer, Berlin (1996). 